\title{
Learning to Teach, Learning to Play the Game: A Case Study of a Minority Teacher Candidate Teaching for Equity, Diversity and Social Justice
}

\author{
Andrew M.A. Allen (University of Windsor)
}

\begin{abstract}
In this article, the author explores the premise that possibilities for social change in an antiracist teacher education program might be revealed by closely examining the struggles and real life experiences of a beginning teacher from a minority background working from the margins of the educational setting. Focusing on the quality of the teaching-learning activities being negotiated and forged, this article is grounded in a study of the tensions, dilemmas and conflicts experienced by teacher candidates learning to teach for social justice. The study revealed that the inherent tensions caused by discontinuities between the intent and critical antiracist philosophy of the program and its actual content, processes and the experience within practicum schools can be necessary for moving teacher candidates in their thinking about antiracist teaching and teaching critically. The article's focus is on one participant from a Latino background who began to come to terms with accepting the existence of tensions and conflicts and became less obsessed with finding definite solutions or resolutions. Explicit discussion of his experiences within all aspects of the program and direct talk about the tensions and conflicts began to help the teacher candidate make sense of his experiences. Critical teaching for equity, diversity and social justice is a journey into teaching filled with risks and uneasiness.
\end{abstract}

\section{Résumé:}

Dans cet article, l'auteur explore la prémisse que l'on peut révéler les possibilités du changement social dans un programme d'éducation antiraciste pour les enseignants stagiaires en examinant de près les luttes et les expériences de vie d'un enseignant stagiaire débutant de souche minoritaire et qui travaille en marge du milieu d'éducation. Se concentrant sur la qualité des activités d'enseigner et d'apprendre en négociation et en formation, l'article est fondé sur une étude des tensions, des dilemmes et des conflits subis par les enseignants stagiaires quand ils apprennent à enseigner la justice sociale. L'étude révèle que les tensions inhérentes causées par les discontinuités entre l'intention et la philosophie antiraciste du programme et son contenu, les processus et l'expérience dans les écoles peuvent être nécessaires pour changer la façon de penser des enseignants stagiaires sur l'enseignement antiraciste et l'enseignement critique. L'article est centré sur un participant de souche Latino-américaine qui commence à accepter l'existence des tensions et des conflits et à devenir moins obsédé par la découverte des solutions ou des résolutions définitives. Une discussion explicite de ses expériences dans tous les aspects du programme et un entretien direct sur les tensions et conflits commencent à aider cet enseignant stagiaire à donner un sens à ses expériences. Enseignement critiquement de l'égalité, la diversité et la justice sociale représente un voyage dans l'enseignement et est rempli de risques et d'inquiétudes et non une destination. 


\section{Introduction}

One of the most salient issues in any discourse around pre-service teacher education, concerns the initial preparation of teachers as the crucial element in confronting and challenging schooling as a site of social reproduction. Critical teacher education is of great importance because schools traditionally tend to perpetuate the status quo by serving the purpose of preparing students to become workers to fit into predetermined roles in society (Giroux \& McLaren, 1986). Some faculties of education in Canada have adopted specific initiatives that recognize the need for teacher candidates, as an integral part of their teacher preparation, to be able to actively name and contest the sources of inequality inherent in the Canadian school system (James, 1994, 1997; James \& Mannette, 2000; Solomon, 1995, 1998; Solomon \& Levine-Rasky, 1996, Solomon \& RezaiRashti, 1997). However, recent studies and ongoing monitoring of teacher candidates in various critical teacher education programs have identified many tensions and contradictions faced by their beginning teachers because of the challenges of learning to teach for equity, diversity and social justice (James, 1994, 1995, 1997; James \& Mannette, 2000; Olikow \& Young, 1993; Solomon, 1995, 2000; Solomon \& Allen, 2003).

In this paper, I will focus on the experiences of one teacher candidate, Nigel, selected from among 40 others in a larger study on teaching for social justice (Allen, 2003). Following Adams, Bell \& Griffin (1997), I define social justice in education as activities that address social inequities and oppression in society. Education is neither a neutral nor a political process. Teaching for social justice involves strategies and approaches that aim to enable the full and equitable participation of all groups in society and is therefore difficult and messy. It involves also giving voice and agency to traditionally marginalized groups to create social change through their own self-determination. Nigel's case is illustrative of the challenges, dilemmas and tensions that teacher candidates deal with in their efforts to teach critically and for social justice during their teaching placement.

Through discussing Nigel's case, I will explore how teacher candidates negotiate these tensions and challenges, as well as the inherent contradictions between faculty of education course content and the classroom practices of the supervising teachers from whom they are expected to learn. Put differently, I examine some of the strategies this teacher candidate adopted as he also learned to "play the game" during his school practicum and consequently ensured himself safe passage through the broader teacher education program.

Methodologically, the case presented here is part of a broader critical ethnography in which I conducted in-depth interviews and observed teacher candidates during their teaching practice in schools. All interviews were audiotaped and transcribed. Following transcription, the data was recycled through the 
participants for member checking. Although Nigel was enrolled in the teacher education program I taught in, he was located on a different campus, and was not one the teacher candidates for whom I had any responsibility. I visited Nigel in his practicum classrooms, emailed him, and met with him on neutral ground on campus. I was also provided with access to his program materials, including reflective journals and some course assignments.

In his interview responses and program materials (reflection journals, course assignments), I looked for continuity or discontinuity to establish emerging themes. I examined closely his critical reflections on assigned course readings, materials generated from student-prepared seminars, and course essays. I analyzed the resulting data for the teacher candidate's beliefs and philosophies about teaching, for hints on whether he was adopting a critical teaching practice, and his expectations for and his feelings about his year of learning to teach. Overall, I was particularly interested in his developing perceptions of himself as a critical teacher.

Nigel is a student of Latino and working class background and when I asked, he chose to describe himself simply as "a revolutionary" for this study. He found that much of the combined discourse of the practicum and the general program around working with students in urban working-class inner city schools did not find its way into the practices of the program itself. Put differently, Nigel argued that while professors in the urban education program taught about how to work with students in inner-city schools, they themselves failed to address the needs of teacher candidates from these same locales.

I chose to focus on this particular candidate's experiences because he made a lasting impression on me. I was intrigued by his expressed frustration with the teacher education program and his insights into the types of strategies he employed to work within the program. I found his responses particularly insightful because of his expressed commitment to social justice issues and his unique struggles with the tensions in his program. In that way, his practicum classroom became an active site of struggle; and thus, I wanted to investigate the ways in which he attempted to teach for social justice and negotiate a critical teaching practice. I wanted to learn more about the ways he negotiated a critical and inclusive space in the practicum and some of the consequences resulting from his taking up the challenge of adopting a critical teaching practice.

In this paper, an analysis and reflection on Nigel's experiences also inform my own thinking and my experiences now as a practicum faculty advisor and critical or antiracist teacher educator. As a former supervising classroom teacher and former teacher candidate myself and having gone through the same program nine years before Nigel, I am interested in the ways Nigel's experiences may give insights into his engagement with the tensions in the practicum. Therefore, it is important to mention here that the questions I raised in the broader 
study (Allen, 2003) were designed to bridge some of the gaps in my own research, teaching and learning. In this case study, I present Nigel's experiences as only one part of a whole group of other teacher candidates. For the larger study, I used critical ethnographic methods as a way of acknowledging my social and institutional identities (both past and present) and how I deal with tensions today with teacher candidates in my program.

Critical ethnographic methods also helped me to interrogate my location and power in the research process; that is, the historical legacy associated with research methodology and the traditional positivist Westernized patriarchical notion of the researcher-participant relationship. This is the kind of reflexive process that Smith (1999) refers to in her research with indigenous participants. Reflexivity refers to the researcher's conscious self-referential understanding of the research process (Hammersley \& Atkinson, 1983; 1995), or more specifically, to a sceptical approach to the testimony of respondents (i.e., Are they telling me what I want to hear?), and to the development of theoretical schema (i.e., Am I seeing what I want to see?).

Throughout the year, I became much of a listening ear, that at times the research participant would seek me out because he wanted to tell me his stories of his experiences in the program. For example, he would see me in the hallways, approach me and tell me that he really needed to tell me more about his experiences in the schools. In listening to him, I realized how much I had taken as normal the every day struggles of teacher candidates because I had gone through the program myself. However, in listening to Nigel and others, I realized that such experiences were uniquely undergone by those students who, during their teaching placement, addressed social justice issues. In reflection, I believe that because of my teacher/evaluator relationship with my own teacher candidates in the program, they were reluctant to talk to me about the tensions and struggles they were experiencing so as not to appear incompetent. It is important to reemphasize that I was not Nigel's faculty supervisor, (nor that of any of the other teacher candidates who were part of the broader study), and thus he saw my role as an observer and not an evaluator. In this regard, then, the research process provided a forum for me to listen to one of the frequently silenced voices in the teacher education program in the faculty; as well, it provided the teacher candidates a space to talk among themselves.

The teacher education program was designed specifically to prepare teachers to teach for equity, diversity and social justice. The course content was developed using antiracism principles, as defined by Dei (1996). For Dei, antiracism education is an action-oriented strategy for institutional, systemic change aimed at addressing racism and the interlocking systems of social oppression. Teacher candidates are recruited from underrepresented groups to join the program, taught to view antiracism education as a specific approach to 
teach for social justice, and are placed for their practicum in mostly urban communities so that they able to apply principles in practice in their teaching.

\section{Theoretical Framework}

Perhaps, the biggest challenge for any teacher candidate learning to adopt a critical approach to their teaching is deciding which social issues they will raise and how they will raise these issues with their students. These issues include equity, social justice, social difference, power relations and the oppression and marginalization of various groups in society (Cherian, 2001).

Often, even introducing and taking up critical social issues with students in the classroom may cause unexpected tensions because of the potentially conflicting perspectives that students, the supervising teacher, and other school personnel may hold (Graham, 1997). Furthermore, tensions may arise because of different views and perspectives that may exist across groups of students. This tension becomes more pronounced when the supervising teacher and the practicum schools are unsupportive of raising critical social issues that might require social justice interventions. In such instances, teacher candidates often feel pressured to conform to the general culture of the schools in which they are placed and abandon engaging in such a potentially contentious arena. Thus the year of learning to teach can become a year of conformity - learning to not ask questions, to "stick to the program," "play the game" and "keeping your mouth shut" (see Allen, 2003). Such learning has serious implications for wellintentioned teacher educators since it renders impotent their desire to promote a critical teacher education.

I use the term "critical" in a very broad sense when referring to teacher candidates' approaches to their practice teaching experience. As such, critical social theory is thought of as drawing from a broad range of fields: cultural studies; gender studies; feminism; antibias, antidiscriminatory and antiracist education; and a cluster of pedagogical approaches (critical pedagogy, feminist pedagogy, antiracism pedagogy and Freire's Conscientization) dedicated to an emancipatory agenda of equity and the abolition of social injustice. I use also the term "critical teaching practice" in a general sense to refer to any approach that seeks to help reduce, remove, and overcome institutional barriers and promote proportional participation and comparable achievement of people that are traditionally under-represented in the school system. It refers also to any form of teaching practice that seeks to sustain and recreate communities of caring and advance participatory power for poor and minority children.

Discontinuities and Contradictions in Teacher Education

The movement between teacher candidates and the social structures are ... an interaction of contradictory forces ... Discontinuities and 
contradictions are encountered at every turn. This is especially evident when teacher education prepares teacher candidates for racial and ethnic diversity in the schools (Levine-Rasky, 1998: 89).

Several progressive teacher educators have explored the pedagogy and politics of preparing teachers for a more socially just society and have identified inherent contradictions and tensions in teacher education (Britzman, 1991b; Delpit, 1995; Giroux \& McLaren, 1986; Levine-Rasky, 1998; Liston \& Zeichner, 1990; Sleeter, 1992b; Solomon \& Levine Rasky, 2003; Sykes \& Goldstein, 2004; Zeichner, 1993; 1996). This has become even more important in a society that is becoming increasingly racially and sexually diverse. Thus, the challenge of preparing teacher candidates for diversity in schools and to work for social justice is now even greater. For example, teacher candidates are placed for practicums in urban classrooms that reflect a range of social and cultural differences. However, teacher candidates' own subjectivity impacts how they teach those who are socially and culturally different from themselves (Saul \& Wallace, 2002). Furthermore, how teacher candidates negotiate these social differences during their practicum will be shaped by what they have learned in the program. What further compounds an already difficult situation is that teacher education programs are themselves already full of contradictions and unresolved dilemmas (LevineRasky, 1998).

Levine-Rasky (1998) argues that in order to understand the tensions teacher candidates encounter in trying to adapt to the contradictions and dilemmas in schools, we need to understand the role of teacher education in the production of subjectivities of both new teachers and their students. According to her research, teacher education implies an identity formation and moral regulation of prospective teachers as human subjects and the production and reproduction of social structures and relations between particular social groups.

Britzman (1991a; 1991b) points out that the arena of student teaching opens up understandings into the ways our teaching selves are constituted in the process of learning to teach. She argues that it is through the process of learning to teach that teachers begin to confront the multiple meanings, constraints, and possibilities of the teacher's identity. Britzman argues also that taking up a teacher identity can mean suppressing aspects of the self. Consequently, this duality of teacher identity formation and simultaneous suppression of "self" creates conflict for teacher candidates. Therefore learning to teach involves a dual struggle that tends to construct the experiences of the teacher candidate as the site of conflict.

It is the instances in the classroom where critical issues are raised and confronted in the teacher candidate's lessons with their students that become sites of struggle, negotiation, accommodation and/or resistance. The practicum 
experiences for the teacher candidates become tension-filled when they attempt to teach in ways that are required in their teacher education program. Thus, contradictions and resulting tensions are an expected and necessary part of learning to teach critically.

\section{Negotiating Tensions}

[P]reservice teachers in particular [need] to understand that there is no nirvana or shiny happy people and unproblematic pristine language at the same time as they have some ideas what they might do to "work with/ against the grain" in their classrooms (Thomson, 2002:108).

The discontinuities and contradictions in teacher education can be a particular site for tension in the program and open up discussion about teacher candidates' social identities. For example, the same critical activism that seeks to challenge and address issues of social injustice and inequity also raises questions about the teacher candidates' power, privilege and the relationship between their raced, classed and gendered identities in the classroom and school and society in general. Levine-Rasky (1998) describes teacher candidates' identity formation as dialectical; being shaped and, at the same time, shaping their multifaceted and competing identities. The process of learning to teach is filled with tensions and it is the negotiation of these tensions that opens up possibilities for transforming teacher education.

Thus, tensions caused by the conflicts, dilemmas and dissonance in learning to teach are perhaps integral or necessary elements in helping teacher candidates to reframe their thinking. For example, Levine-Rasky (1998) suggests that teacher candidates, like experienced teachers, come with preconceived notions about teaching and their attitudes towards working for social justice in dealing with culturally diverse groups of students are often set before they even enter the program.

It is only through struggle and reframing - socialization, critical reflection, application, contextualization, internalisation of values and knowledge about cultural diversity, and developing an imperative for change - that teacher candidates begin to experience a major shift in their thinking about these issues (Levine-Rasky, 1998). Therefore, teaching critically while learning to teach involves negotiating tensions and having the moral courage to be willing to explore and address those tensions (Jakubowski \& Visano, 2002). It involves an attempt to explore how teacher candidates' constructs, values, knowledge, and ways of being informed by their multiple identities are reshaped through the social and political process of the teacher education program, the practicum experience, and society. These multiple identities are all called into question and become a source of conflict and contention in the urban and cultural communities in which they are learning to teach. The greatest challenge facing teacher education today 
becomes: how do we engage teacher candidates to work and cope productively with tensions in their practicum? More specifically, what are the challenges and critical engagement experiences of doing practicums where pedagogy and politics are often in conflict?

Teacher Education as Learning to Live with Tensions

An important missing element in teacher education is acknowledging the existence of tensions and contradictions. Teacher educators need first to understand that the process of negotiating tensions in learning to teach involves uncertainty, rationalization and compromise (Dudley-Marling, 1997) before they can begin to help teacher candidates to negotiate these tensions. Levine-Rasky (1998) argues that teacher candidates need to understand that teaching is a continual process of coming to terms with tensions and living with unresolved issues, or developing a rationale for accepting the prevailing incongruence and consequences in teaching. Hartnett and Carr (1995) further suggest that it is important also that teachers start grappling with complex moral and political issues at the initial stages of learning to teach.

In summary, the critical transformative agenda of a critical teacher education program is inherently tension-filled and can cause discontinuities and contradictions. Perhaps, these same tensions may become points of learning for the program. It is in this vein that I now turn to the voice and experiences of one particular teacher candidate. His perspective is one that is often neglected in the literature. I also offer ways in which teacher educators can help teacher candidates to negotiate or deal with the resulting tensions and contradictions they experience during the practicum component of learning to teach.

Nigel's Classroom: Learning to Play the Game

Nigel's fifth grade classroom was unique in its set up and teaching approach compared with other classrooms in his practicum school. Students' desks were all arranged in a " $\mathrm{u}$ " shaped formation facing the front of the class. The walls and bulletin boards had posters and chart paper with study notes and class notes. There was little evidence of student work posted around the room as is typical of other classrooms for this grade level in most schools. Students worked mostly out of workbooks or worksheets that were neatly piled on a table in the back. Most of the lessons were delivered through direct teaching or lecture style where the students copied notes from the board and worked out of various text books or readers. Almost all of the 30 students were from traditionally marginalized groups and since the school was located within a very diverse working-class community, it is safe to conclude that almost $90 \%$ of the students came from working-class families. The majority of students lived in government subsidized housing in the local school community. 
Nigel's discussion of learning to teach involved the discourses of advocacy and risk-taking, and was specifically focused on working-class students. As a consequence, the political practicum engagements he undertook had personal and professional ramifications. In some instances, he found himself in unsupportive school environments where his supervising teachers restricted the type of work that he could do. It was this aspect of learning to teach critically that I am most interested in. That is, I was particularly interested in the points in the program where teacher candidates had to deal with contradictions and tensions and/or how they began to negotiate a critical inclusive teaching practice. I will argue that even in situations where teacher candidates are eager, willing and committed to addressing issues of social justice in the classroom, the struggles of teaching critically are more complex than we have come to expect. An examination of the moments of engagement with contradictions and tensions offers insights into the struggles and dilemmas teacher candidates face in the program and the types of support they need to help them construct meaning when dealing with educational decision makers.

\section{"I feel like I am selling the best thing in me for a job in the future"}

In our initial discussions, Nigel felt that his associate teacher was unsupportive of the critical ideas or activism he brought from the faculty. For one of my visits, Nigel had planned a unit of study on the local community for the grade five students in his practicum classroom. As a person of colour, Nigel found that talking about race and oppression and using himself as an example were clearly within his comfort level in his teaching. Nigel encouraged students to bring their own personal and family stories about their experiences of racism and discrimination in their community.

During this lesson, Nigel attempted to remain within the boundaries of the posted curriculum because his lessons were all reviewed by the supervising teacher. This was because he had quickly learned of his mentor teacher's seemingly passive acceptance of a curriculum and pedagogy he perceived as unresponsive to equity and diversity issues. However, this particular lesson was one that Nigel felt free to modify to include discussions about social issues because the supervising teacher was out of the classroom for most of the lesson. During the discussion, he asked the students to identify some of the issues they see facing their own community or things they felt needed to be changed. He prompted the students so they would give specific examples like crime, pollution and poverty. The students were encouraged to talk about the reasons they felt that those issues were prevalent in their community. Students also had an opportunity to examine articles from newspapers that featured stories about their community. Once the students were able to identify some of the problems facing their 
community, he allowed them time to begin devising strategies for bringing about change in their community.

As previously mentioned, Nigel's background is also working-class and, as a way of engaging the students he used himself as an example for the students to draw upon. While such self-positioning was successful in this lesson, Nigel lived with the fear of teaching, or continuing to take such a risk of teaching, for social justice in an unsupportive environment. During the follow-up lesson, Nigel kept looking over at his supervising teacher at various points to gauge the mentor's reaction. For most of the lesson, Nigel's supervising teacher sat quietly in the back of the room, observed and took notes on Nigel's lesson. In our discussion after the lesson, Nigel spoke mainly of the pressures of being a teacher candidate trying to teach for social justice in a very conservative and perhaps not socially just environment.

It was a matter of survival. You have to survive. Survival is not enough. It has to mean something. You feel like you are just surviving for yet another day with not telling the supervising teacher that he is an idiot. The way he is treating those kids in his class is just terrible; psychologically, emotionally and spiritually. I feel I am being cheated in this program and that I am cheating myself. I find myself reproducing the status quo. We are supposed to be change agents. We are not changing anything. I feel like I am selling the best thing in me for a job in the future.

Nigel had learned to cope in the practicum by following the lead of his supervising teacher and to avoid issues of social justice. He learned not to try to change the structure of the practicum classroom.

There was a lot of animosity between myself and the supervising teacher. I was seen as a burden. At times, I was made to feel as if I was supposed to know everything. As I said, it was like being in the army. You learn to just do as you are told. Even the faculty advisor was not able to lead by example. ... They thought about me, "This guy is not a teacher." I believe that they had made up their minds about me.

On a couple of occasions, the supervising teacher would briefly interrupt Nigel's lesson on the community with questions for the students to encourage them to focus their responses on communities in general and not specifically their on own community. At other times, he gave Nigel a disapproving gaze to prompt him to stay clear of explicitly personal issues in his discussions with the students. In his feedback after the lesson, the supervising teacher encouraged Nigel to stick to the curriculum and not to stray too far from the content as written in the curriculum document. 
The consequences for Nigel of teaching for social justice as a teacher candidate were serious. He felt that his supervising teacher had interrupted his lesson to give what he perceived as negative feedback about his critical approach and social justice orientation to teaching. Nigel felt that the teacher was actively discouraging him from engaging such practices in the practicum. Therefore, his approach to teaching did not meet the approval of his supervising teacher and would jeopardize his successful completion of the practicum.

My take on this program is that of an antiracist educator. It is an ideological stand point to fight racism. I believe I got into trouble because I brought my politics into the practicum classroom. They did not like that. I feel that I was strongly discouraged from taking on any issues. If I did, then I was punished.

When I asked Nigel about the ways in which he made sense of his experiences as a teacher candidate trying to teach for social justice, this is what he had to say:

But, I thought that this was what this antiracism program was all about. Why would they give us a program [with course and philosophies] that calls for us to take on more radical approaches to teaching and learning and then kill it once we get into the practicum classroom.

Nigel felt that he was actively discouraged from teaching outside the prescribed curriculum. He learned to maintain a strict adherence to the conservative ethos of his practicum classroom:

For example, last term I wanted to teach a unit on pioneers with my Grade 3 class. I decided to turn it around a bit and look at the Native or Aboriginal peoples and the first or the pioneers in this country. My supervising teacher shut everything down for my lesson. He prohibited me from teaching that. I believe that he wanted me to stay clean or to stick with the soft issues. Again, the one thing I learned was, "Do not ever rock the boat.”

However, Nigel was aware of the consequences of simply sticking to the established curriculum and postponing his attempts at teaching for social justice. As we shall see in the next section, he found it quite difficult to pretend to teach in traditional and conservative ways while putting off his desire to teach for social justice.

"By that time [when I get out of the program] it is too late. We are already coopted into the system"

In the next example, Nigel identified one of the main impediments to preparing teachers to become critical teachers. The year of learning to teach is vital as 
teacher candidates are less likely to become critical teachers if the application of social justice issues does not become a part of how they learn to teach. At times, Nigel resorted to convenient occasions and "teachable moments" to integrate sensitive issues such as those dealing with sexual orientation and homophobia into his pedagogy.

So what I did was write my lesson plan in a way that did not offend [the mentor teacher] and teach the way he wanted to when he was watching. Then when he was out of the room or when he wasn't looking, I would do my own thing. A couple of times, he was sick and they had a substitute teacher in for him. I had a really great lesson with the kids. I believe we are doing them a disservice right now. It is foolish for me to say, "I am going to wait until I get my own classroom next year." If we do that, we may never ever learn to teach for social justice. We keep saying, "I'll wait until I get out of the program, then I can do what I want." Then when we get the job we say, "I'll wait until I make my probation, then I can do what I want.” By that time it is too late. We are already co-opted into the system. We have already developed bad habits that are hard to break. We become a part of what we started out fighting in the first place.Nigel reported that whenever he submitted his lesson plans to the supervising teacher, he normally excluded any form of social justice initiative in his written plans and made mental notes of spaces within the lesson where he could take up critical and social justice issues. He talked about looking out too for spontaneous moments within the lesson where the students themselves might raise critical and social justice issues for discussions. He discovered that once the students realized that talking about issues of race, class, gender and power, for instance, was encouraged, they began to open up and talk more freely about these issues. For the most part, those issues were never otherwise discussed in the classroom.

Nigel's engagement with the pedagogy of equity and social justice depended, to a large extent, on his supervising teacher's classroom politics and commitment, or lack thereof, to diversity. The supervising classroom teacher's pedagogical stance, as Nigel perceived it, appeared to be located in the extent to which he had bought into the standardized curriculum, his politics as a teacher, and his level of commitment to democratic ideals. In turn, Nigel learned to observe and respond to this traditional and conservative environment by resisting standardization in deceptive and often contradictory ways.

SUMMARY

It is evident from the preceding discussion that for Nigel, it took some time before he realized that he had to abide with the stated and unstated expectations and 
follow established teaching practices. He eventually realized that learning to teach meant following the supervising teacher's lead and adhering to the school ethos in order to survive the practicum. Consequently, Nigel developed a duality in how he approached the theoretical and practical components of the program. In my observations, some supervising teachers would sometimes mediate the relationship between a teacher candidate and the practicum students. For example, in Nigel's case, his supervising teacher often interrupted his lesson to ensure that the pre-established norms of the classroom were preserved. Nigel became acutely aware of the power relationship in the classroom and quickly learned that his role was to be submissive and to imitate the supervising teacher. The curriculum governed the relationship between that supervising teacher and the teacher candidate. This pressure to please the supervising teachers and evaluators resulted in "doing what the teacher does." Candidates were stripped of creativity, their lived experiences and perspectives were marginalized. The candidate's classroom role became submissive.

It is interesting to note how Nigel became very strategic in his responses to teaching for social justice in his practicum classroom. In his course work, he indicated that he wanted to see social justice-based teaching practice become central to the teacher education program and his journal entries reflected favourably on the idea of teachers as critical change agents. An analysis of his classroom approach revealed covert strategies in dealing with social justice issues in the classroom, where on the one hand, teaching what he considered safe became a starting point for engaging in more complex issues. On the other hand however, Nigel employed accommodation strategies by suppressing his personal beliefs in order to conform to his supervising teacher's expectations.

The social and political contexts of the practicum severely restricted the extent to which Nigel could engage in reflective, critical and enquiring practice. Studies of candidates in practicum schools (Menter, 1989; Grant and Zozakiewicz, 1995) are insightful in exposing how the maintenance of the "status quo" within school cultures impedes the practice of teaching for social justice. Menter's analysis of the traditional apprenticeship approach to teacher education provides the picture of the triad: the candidate, the supervising teacher and the faculty advisor locked in a relationship characterized by "stasis." The institutional culture of the school and its power relations socialize members of this triad into ways of behaving so that conflicts and tensions are minimized or avoided altogether. Menter observes, "All members of the triad seek to minimize, counteract or negate any influence or innovation which might upset the stability of the triad" (p. 470).

To safeguard against the tensions that may arise between teacher and teacher candidate, some candidates retreated into "silence". Grant and Zozakiewicz (1995) describe such silences as 'the lack of critical discussion regarding multicultural education, as it relates to social justice issues’ (p. 267). 
Teacher candidates often endure "stasis", a tactic that facilitates maintaining the status quo within practicum schools, by engaging in "silences" on issues of equity and diversity, and simply wait until they "get their own classrooms" before they engage in critical teaching, equity and social justice issues (Grant \& Zozakiewicz, 1995; Menter, 1989; Solomon \& Allen, 2003). Nigel engaged in these practices as he struggled to go through his practice teaching.

As Nigel moved into the field with visions of schooling for equity and social justice, he encountered an institutional culture that maintained a rigid structure of relationship between administrators, teachers, students and parents. He found himself disempowered at the bottom of a school hierarchy that avoided the exploration of social differences; that is, race, class, ethnicity, gender, and sexual orientation.

\section{Conclusion}

There are a number of implications for teacher education that can be gleaned from this examination of Nigel's experiences. Teacher candidates must see teaching for social justice not as a panacea or palliative (Lee, 1994), but as filled with continual tensions and conflicts. Indeed, it entails ongoing struggles alongside developing appropriate classroom management, planning and classroom interactions while establishing a teaching identity. There are no quick solutions or easy answers. Providing learning environments that nurture a dialogic relationship between the academic discourse of the teacher education program and the implementation of social justice practices during the practicum is an essential starting point in progressive teacher education. Approaches that facilitate infusing issues of equity, diversity and social justice into teaching are hardly examined in teacher education. Literature addressing the practicum challenges discussed above would enlighten teacher candidates with strategies for teaching issues counter to the hegemony and for creating positive relations with the supervising teachers.

There is also a delicate balance to be maintained between encouraging teacher candidates to be critical and having them respect and appreciate the years of experience of the supervising teachers and the knowledge and familiarity they have with their classrooms. Teacher candidates have much to learn from supervising teachers as they try to figure out their own teaching identities. They need to learn to avoid the trap of rejecting everything they see in their supervising teachers' teaching and approach because of how different they are from their own or what they have come to expect. Although Nigel appeared to be disillusioned by the ways the supervising teacher conducted his classroom, I observed Nigel modelling and implementing some of the classroom routines and expectation that had been established by the teacher. He perhaps was not consciously aware of it 
nor was he able to speak about the skills and experiences he had learned from supervising teacher.

Several forms of teacher responses to contradictions and tensions described as 'playing the game' are also reported elsewhere in the research literature. For example, McNeil (2000) describes how teachers were able to work within curriculum guidelines while teaching more responsively to the perceived needs of their students.

It caused them to have to play games in front of their students, appearing to conform while attempting to teach. It trivialized the curriculum by transforming the content of school into testable pieces scarcely recognizable as components of academic subjects. ( p.215)

The teachers employed a "double-entry" strategy to comply with the official proficiency-based curriculum while continuing to teach to the "real" curriculum. This "real" curriculum constitutes the more substantive information, the acquisition of skills, the complex content students require to function in an evolving society. Here, McNeil provides more insights into teachers' responses and their potential impact on the teaching-learning process. One of the issues evident in Nigel's practices is how he dealt with contradictions through 'playing the game' and simultaneously moved beyond the 'game.' Nigel would have benefited from a collaborative group discussion at the faculty connecting his own lived experiences to the theories discussed in the program.

As we have seen from Nigel's particular experiences, the types of 'games' he felt he needed to play in his practicum classroom, meant finding teachable moments to teach for social justice. For Nigel 'playing the game' was a way of avoiding conflict or tensions with his supervising teacher and of ensuring a safe passage through the teacher education program. However, it is necessary to move teacher education discourse beyond condoning just playing games to developing strategies and negotiating space within the practicum setting for supporting teacher candidates in their attempts to teach for social justice. Normally, teacher candidates fear reprisal and poor evaluations in their practicum. But the year of learning to teach is crucial if beginning teachers are to become teachers who teach for social justice. As evidenced by Nigel's case, teacher candidates may fear that they will become co-opted into playing the game for the rest of their careers and never become the type of teacher they wanted to be when they entered the teacher education program.

Negotiating space for teacher candidates can mean learning how and when to attempt to teach critically in their supervising teacher's classroom. As we have seen from the data in this study, some teacher candidates learn to compromise their teaching approach in order to appease their conservative mentors. Teacher candidates felt that they were being discouraged from taking a 
critical approach to their teaching. They feared that their mentors and evaluators might penalize them in those situations and this might inhibit their chances of making it successfully through the teacher education program. Teacher candidates learned to teach to the standardized curriculum and wait until they had completed the program and become classroom teachers themselves before they could begin to teach critically.

Teacher educators could then provide more space for discussions about some of the more difficult or potentially controversial social issues while continually encouraging open dialogue and feedback from teacher candidates. Teacher educators need to facilitate the planning of social action by teacher candidates. They could help candidates identify potential pitfalls and difficulties they might encounter. The selection of practicum classrooms that encourage and support these initiatives is crucial. However, in cases where candidates are in unsupportive classrooms, teacher educators need to help candidates acknowledge the difficulties and challenge of working under such conditions and get them to explore strategically appropriate responses. For example, teacher candidates could find spaces within the school day and the curriculum to teach for equity and social justice (see Solomon \& Allen, 2003). Teacher candidates need to develop constructive and productive ways of bringing about change even when faced with resistance and restrictions. These could include negotiating with mentors and selecting issues that might not cause as much discomfort for them. For example, teacher candidates could find out the kinds of issues the mentor intends to cover in their classroom. They might ask to teach some of those issues or ask to review and follow up on those issues.

Finally, I would suggest introducing a mechanism within teacher education programs for more open discussion and debriefings on teaching for social justice. This involves risk and has the potential for causing contentions in the program. However, such discussions could be guided and open for critique. What I am suggesting is a delicate balance that requires mediation skills by teacher educators. Candidates must realize that the process is long and painstaking and that not all issues will be resolved and completely dealt with even by the end of the program. The sharing of faculty members' stories is another way of bridging the gap. If the theoretical discussions in the program are grounded in some of the experiences of the instructors as teachers, teacher candidates will be better able to make connections to their practice. Sharing stories and reflections on practice based on success, as well as, failure is essential if teacher candidates are to understand teaching as a learning process where teachers are always reflecting on their practice.

The findings from this study serve to inform on-going discussions and restructuring of both pre-service programs. This research adds to the discussion by offering the unique perspective of teacher candidates and their responses to the 
way they are being taught to teach. It suggests further implications for critical teacher education programs including those with a focus on any kind of activism discourse or antiracism pedagogy. Such teacher critical education programs need to be grounded in the realities of the teacher candidates. There are also implications for critical teacher education curriculum and teacher development. Teacher education curriculum should be restructured to incorporate the taking of risks and teaching for social justice. This will entail a review of the content of teacher education courses and curriculum, as well as, the delivery and implementation of these programs. For example, integration of social justice in all aspects of the teacher education program is a main theme that runs through the analysis of the data in this study. This suggests greater collaboration with all parties involved in the teacher education process and a sustained explicit effort to make clear connections between all aspects of the program.

\section{References:}

Adams, M., Bell, L.A., \& Griffin, P. (1997). Teaching for Diversity and Social Justice: A Sourcebook. New York: Routledge.

Britzman, D. (1991a). Decentering Discourses in Teacher Education: Or the Unleashing of Unpopular Things. Journal of Education, 173(3), pp. 60-81.

Britzman, D. (1991b) Practice makes Practice: A Critical Study of Learning to Teach. Albany NY: SUNY Press.

Britzman, D. (1996). That Lonely Discovery: Anne Frank, Anna Freud and the Question of Pedagogy. Unpublished manuscript.

Britzman, D. (1998). Lost Subject, Contested Objects: Toward a Psychoanalytic Inquiry of Learning. Albany NY: SUNY Press.

Cherian, C. (2001). Really Teaching for Social Justice. Orbit. 31(4), pp.

Dei, G.J.S. (1996). Anti-racism Education: Theory and Practice. Halifax NS: Fernwood Publishing

Delpit, L. (1995). Other people's children: Cultural conflict in the classroom. New York: The New Press.

Dudley-Marling, C. (1997). Living with Uncertainty: The Messy Reality of Classroom Practice. Portsmouth NH: Heinemann.

Giroux, H. \& McLaren, P. (1986). Teacher Education and the Politics of Engagement: The Case for Democratic Schooling. Harvard Educational Review, 56(3), pp. 213-238.

Gomez, M. (1996). "Prospective Teachers' Perspectives On Teaching 'Other People's Children'.” in M. Gomez, S. Melnick, \& K. Zeichner. (Ed.) Current Reforms In Pre-Service Teacher Education (pp. 109-132). New York: Teachers College Press. 
Graham, P. (1997). Tensions In The Mentor Teacher-Student Teacher Relationship: Creating Productive Sites For Learning Within A High School English Teacher Education Program. Teaching and Teacher Education, 13(5), pp. 513-527.

Grant, C.A. \& Zozakiewicz, C.A., (1995). Student Teachers, Cooperating Teachers, and Supervisors: Interrupting the Multicultural Silences of Student Teaching. In J.M. Larkin \& C.E. Sleeter (Eds.) Developing Multicultural Teacher Education Curricula (pp. 259-278). Albany: State University of New York Press.

Hammersley, M., \& Atkinson, P. (1983). Ethnography: Principles in practice. London: Tavistock Publications.

Hammersley, M. \& Atkinson, P. (1995). Insider Accounts: Listening and Asking Questions in Ethnography: Principles in Practice (2 ${ }^{\text {nd }}$. Ed.) (pp. 124-156). New York: Routledge.

Hartnett, A. \& Carr, W. (1995). Education, Teacher Development and the Struggle for Democracy. In J.Smyth (Ed.), Critical Discourses on Teacher Development (pp. 39-53). Toronto:OISE Press.

Jakubowski, L. \& Visano, L. (2002). Teaching Controversy. Halifax:NS. Fernwood Publishing.

James, C.E. (1994). "Access Students": Experiences of Racial Minorities in a Canadian University. Paper presented at the Society for Research into Higher Education's Annual Conference, 1994 - The Student Experience, at the University of York, York, England.

James, C.E. (1995). "Reverse Racism": Students' Responses to Equity Programs. Journal of Professional Studies, $\underline{3}(1)$. pp. 48-54.

James, C.E. (1997). Contradictory tensions in the Experiences of African Canadian in a Faculty of Education with an Access Program. Canadian Journal of Education. 22(2). pp. 158-174.

James, C.E. \& Mannette, J. (2000). Rethinking Access: The Challenge of Living with Difficulty Knowledge. In G. Dei \& A. Calliste (Eds) Power, Knowledge and Anti-Racism Education A Critical Reader. Halifax: Fernwood Publishing.

Kelly D. \& Minnes Brandes, G. (2001) Shifting Out of “Neutral”: Beginning Teachers' Struggles with Teaching for Social Justice. Canadian Journal of Education. 26(4). pp. 437-454.

Lee, E. (1994). Anti-racist Education: Panacea or Palliative. Orbit, 25(2), 22-25

Levine-Rasky (1998). Teacher Candidates and The Negotiation Of Social Difference. British Journal of Sociology of Education, 19(1), pp. 89-112.

Liston, D.P. \& Zeichner, K.M. (1990). Teacher Education and the Social Context of Schooling: Issues for Curriculum Development. American Educational Research Journal, 27(4), pp. 610-636.

McNeil, L.M. (2000). Contradictions of School Reform: Educational Costs of Standardized Testing. New York: Routledge.

Menter, I. (1989). Teaching Practice Stasis: Racism, Sexism and School Experience in Initial Teacher Education. British Journal of Sociology of Education, 10(4), pp. 459-473.

Orlikow, L. \& Young, J. (1993). The Struggle for Change: Teacher Education in Canada. In Verma, G. (Ed.) Inequity and Teacher Education: An International Perspective. London: Falmer Press.

Richardson, V. (1997). (Ed.) Constructivist Teacher Education: Building New Understandings. Washington DC: The Falmer Press. 
Saul, W. \& Wallace, K. (2002). Centering the Margins: White Teachers’ Responses to Roll of Thunder. Teacher Education. 13(1), pp. 41-53.

Sleeter, C.E. (1992a). Resisting Racial Awareness: How Teachers Understand the Social Order from their Racial, Gender, and Social Class Locations. Educational Foundations, 6, pp. 7-32.

Sleeter, C.E. (1992b). Keepers of the American Dream: A Study of Staff Development and Multicultural Education. London: Falmer Press.

Sleeter, C. \& McLaren, P. (1995). Exploring Connections to Build a Critical Multiculturalism. In C. Sleeter \& P. McLaren (Eds.) Multicultural Education, Critical Pedagogy, and the Politics of Difference. Albany NY: SUNY Press.

Solomon, R.P. (1995). Why To Teach From A Multicultural and Anti-Racist Perspective? Race, Gender \& Class. 2(3), pp. 49-66.

Solomon, P. (1998). Reconstucting Teacher Education for Educational Equity and Diversity. Caribbean Journal of Education. 19(1), pp.31-51.

Solomon, R.P. (2000). Exploring Cross-race Dyad Partnerships in Learning to Teach. Teachers College Record, 102(6), pp. 953-979.

Solomon, P. \& Levine-Rasky, C. (1996). Transforming Teacher Education for an Antiracism Pedagogy. CRSA/RCSA, 33.3.

Solomon, R.P. \& Levine-Rasky, C. (2003). Teaching for Equity and Diversity: Research to Practice. Toronto, On: Canadian Scholars' Press.

Solomon, R.P. \& Rezai-Rashti, G. (1997). School-University Partnership in Teacher Education for Educational Equity and Diversity. A paper presented at the Canadian Society for the Study of Education Conference. St. Johns, Newfoundland.

Smith, L.T. (1999). Decolonizing Methodologies: Research and Indigenous Peoples. New York/London: Zed Books Ltd.

Sykes, H. \& Goldstein, T. (2004). From Performed to Performing Ethnography: Translating Life History Research into Anti-homophobia Curriculum for a Teacher Education Program. Teaching Education Journal. 15(1).

Thomson, P. (2002). Muddy Waters and Dirty Discourse(s): Teaching about Social Justice in Teacher Education. Teacher Education. 13(1), pp. 103-111.

Troyna, B. (1994). The 'Everyday World' of Teachers? Deracialised Discourses in the Sociology of Teachers and the Teaching Profession. British Journal of Sociology of Education, 15(3), pp. 325-339.

Zeichner, K.M. (1993). Connecting Genuine Teacher Development to the Struggle for Social Justice. Journal of Education for Teaching, 19(1), pp. 5-20.

Zeichner, K. (1996). Teachers as Reflective Practitioners and Democratization of School Reform. In K. Zeichner, S. Melnick \& M.L. Gomez (Eds.), Currents of Reform in Preservice Teacher Education (pp.199-214). New York: Teachers College Press.

Andrew M.A. Allen is an Associate Professor at the University of Windsor, Faculty of Education. He can be reached at: Email@AndrewAllen.ca 